\title{
Effect of Fire on Lark Sparrow Nesting
}

\section{Densities}

\section{J. DAVID RENWALD}

Highlight: Nests of ground-nesting lark sparrows were censused on seven different ages of burns in a honey mesquite- tobosagrass community in central Texas. Number of nests were negatively correlated with percent cover of tobosagrass. Nests were found in tobosagrass that averaged at least $32 \%$, but no more than $55 \%$ cover. Breeding densities were highest in the most recent burns and declined with increasing litter build-up due to large areas being covered by decadent stands of matted tobosagrass. Clutch sizes for this study averaged 3.7 eggs per nest.

Little information has been published on the effects of various range management practices on nongame wildlife (Buttery and Shields 1975). In Texas, lark sparrows (Chondestes grammacus) are one of the most common ground-nesting songbirds associated with mesquite grasslands (Oberholser 1974). Prescribed burning has been shown to be an effective method in managing the honey mesquite (Prosopis glandulosa var. glandulosa) -tobosagrass (Hilaria mutica) community (Wright 1972). A study was undertaken in the spring of 1975 to

The author was research assistant, Department of Range and Wildlife Science, Texas Tech University, Lubbock. At present he is with the United States Department of the Interior, Bureau of Land Management, P.O. Box 1397, Roswell, New Mexico 88201.

Support for this study came from the Rocky Mountain Forest and Range Experiment Station, Tempe, Arizona. Eisenhower Consortium Pro. No. 16-457-CA.

Manuscript received September 27, 1976. determine the response of ground-nesting and ground-feeding lark sparrows to prescribed fire on seven different ages of burns.

\section{Study Area and Methods}

The study area was located on the Renderbrook-Spade Ranch, 32.2 $\mathrm{km}$ south of Colorado City, Texas. Average precipitation is $48.2 \mathrm{~cm}$ per year. Slopes range from 0 to 3\% on a Stamford Clay soil. Vegetation is dominated by tobosagrass, buffalograss (Buchloe dactyloides), and annual broomweed (Xanthocephalum dracunculoides), with an overstory of honey mesquite and scattered lotebush (Ziziphus obtusifolia).

Areas burned in seven different years were used to evaluate lark sparrow nest sites and establish breeding densities. They included areas burned in 1969 (109.7 ha), 1970 (57.1 ha), 1971 (60.2 ha), 1972 (123.1 ha), 1973 (71.2 ha), 1974 (73.2 ha), and 1975 (91.1 ha).

Nest searches were conducted during the spring of 1975 from June $10-17$ by walking three random transects totaling a distance of 2,000 $\mathrm{m}$ in each treatment. Transects were restricted to tobosa flats or large areas of unbroken topography where fire had its greatest influence. The King strip census method (Hayne 1949) was used to count the number of nesting lark sparrows. The effective flushing distance along each transect or census line was estimated to be $2 \mathrm{~m}$ on either side of the observer. This resulted in a total area census of 1.9 acres $(0.82 \mathrm{ha})$ per treatment.

Vegetational characteristics of the burned areas were recorded using plant height, frequency, and percent cover. These measurements were 


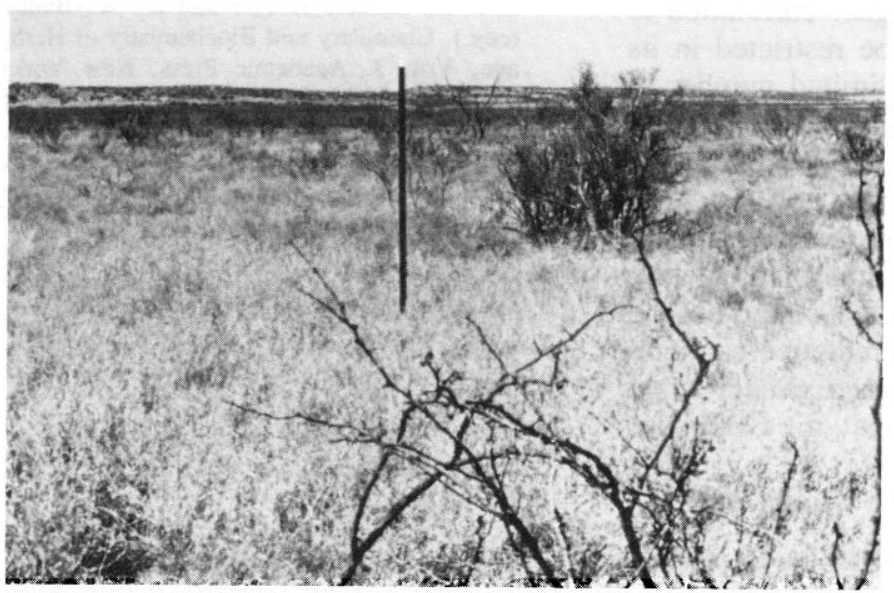

Fig. 1. The 1969 burn where lark sparrow nesting densities were lowest due to the thick tobosagrass cover.

taken at two sites in each burn using 25 randomly located $1.2 \mathrm{ft}^{2}$ $\left(0.11 \mathrm{~m}^{2}\right)$ sampling frames. Plant height was measured to the nearest centimeter. Percent cover estimates were checked using a ten-point frame. Plant height, frequency, and percent cover were also taken at each nest site. Lark sparrow nests were centered within a 4- $\mathrm{m}^{2}$ plot with plant measurements recorded in each $1-\mathrm{m}^{2}$ quadrat.

The type of vegetation that served as the actual nest site was recorded along with the number of eggs per nest. The direction that each nest opening faced was noted to determine if lark sparrows orient the nest to take advantage of shade from grasses during the warmer part of the day.

Several nonparametric tests were used to evaluate the data. Spearman's Rho Test (Conover 1971:248) was used to test for correlations between plant measurements and the number of nests found in each treatment. It was also used to compare cover relationships between treatments and nest sites. The Mann-Whitney Test (Conover 1971:224) was used to compare plant height and percent cover between treatment sites and nest sites.

\section{Results and Discussion}

Breeding densities (pairs/acre) of lark sparrows (Table 1) were highest in the most recent burns and decreased with increased litter build-up and waning grass production due to large areas being taken over by old decadent stands of tobosagrass.

Tobosagrass occurred with the highest frequency (mean $=$ $80.0 \%$ ) and percent cover (mean $=50.6 \%$ ) for all treatment sites; therefore tobosagrass was considered the dominant plant which could affect nest site selection. Buffalograss, the next most frequent plant, occurred $42.1 \%$ of the time. Correlation tests revealed a negative association $(P<0.01)$ between the number of nests found and the percent cover of tobosagrass in each burn (Table 1). The 1969 burn had the highest cover measurements where tobosagrass was thick and matted down with few open areas available for foraging lark sparrows (Fig.

Table 1. Lark sparrows nesting densities and tobosagrass cover $(\%)$ in treatments and at nest sites.

\begin{tabular}{ccccc}
\multirow{2}{*}{$\begin{array}{c}\text { Year of } \\
\text { burn }\end{array}$} & $\begin{array}{c}\text { Number of } \\
\text { nests/1.9 acre }\end{array}$ & $\begin{array}{c}\text { Number of } \\
\text { pairs/acre }\end{array}$ & \multicolumn{2}{c}{ Tobosa cover $(\%)$} \\
\cline { 4 - 5 } 1969 & 6 & 3.0 & 77.5 & Treatment \\
1970 & 4 & 2.0 & 58.2 & Nest site \\
1971 & 9 & 4.6 & 49.4 & 44.4 \\
1972 & 6 & 3.0 & 53.8 & 35.4 \\
1973 & 12 & 6.1 & 46.8 & 37.3 \\
1974 & 19 & 9.6 & 39.0 & 39.7 \\
1975 & 23 & 11.6 & 29.6 & 33.6 \\
& & & & 32.1 \\
\hline
\end{tabular}

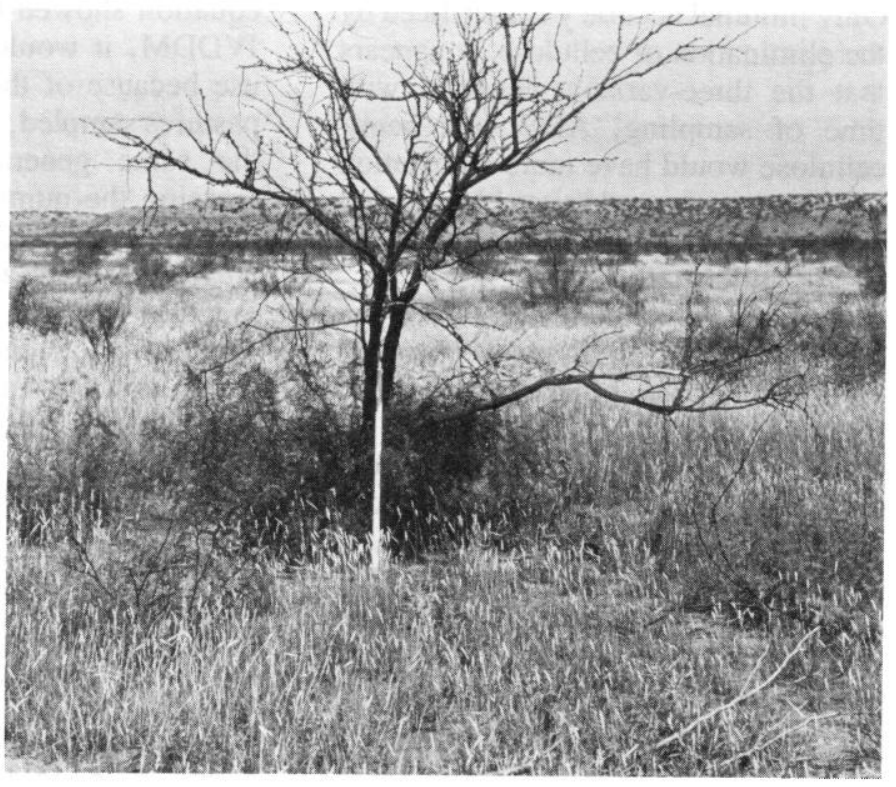

Fig. 2. The 1975 burn where lark sparrow nesting densities were highest due to an adequate interspersion of grassy areas for nesting and open areas for foraging.

1). Six nests were found within the 1969 burn census lines and it appeared that more nest sites were available; however, it may have been the lack of open areas for feeding that influenced nesting densities. At the time of the study, the 1969 burn was 6 years old and litter build-up and decreased grass production had approached that of controls. Wright's (1972) studies in this area of Texas showed that tobosagrass production increases for up to 5 years following burning, when equilibrium is reached. This increase is due to the removal of litter following burning (Wright 1969).

The 1975 burn was located in a stand of tobosagrass similar to conditions which then existed in the 1969 burn. This fire occurred under ideal weather conditions; however, due to early spring rains many green forbs were present to interfere with the combustion of low-volatile grass fuels. The result was a "cool," patchy burn which left many areas untouched by the fire. This burn had the highest number of nests where many open, burned areas remained for foraging and ample, stemmy tobosagrass existed in the unburned areas for nest sites (Fig. 2).

No correlations were found between plant height and frequency data and the number of nests found in each burn. An examination of height and cover data also showed no significant differences between burns and nest sites.

Lark sparrows did select nest sites within a very limited cover range (Table 1). Nests were found in tobosagrass cover averaging at least $32.1 \%$ but no more than $55.4 \%$. A positive correlation $(P<0.01)$ was found between treatment cover and nest site cover of tobosagrass with nest cover averaging higher in older burns.

Out of 79 lark sparrow nests found in all burns, $65(82.3 \%)$ were built in tobosagrass, $12(15.2 \%)$ in buffalograss, and 2 $(2.5 \%)$ in purple threeawn (Aristida purpurea). Nests located in tobosagrass were generally built on the edge of a tuft of grass with one half of the nest constructed with smaller stems and the other half composed of taller tobosagrass stems. Wiens (1974) indicates that ground-nesting grassland birds may be required to spend significant periods of time on the nest shading the young. In this study, $56(86.2 \%)$ nests located in tobosagrass had the more exposed half of the nest facing northeast, away from the 
path of the midday sun and away from the predominant spring wind and rain. This may suggest that nesting lark sparrows oriented the nest to take advantage of the protection offered by taller tobosagrass.

No differences in clutch sizes between burns was noted with the number of eggs averaging 3.7/nest for the study.

\section{Management Suggestions}

The methods for conducting prescribed burns in honey mesquite-tobosagrass communities as described by Wright (1972) should generally benefit ground-nesting lark sparrows. Fires are set early in the spring before the arrival of breeding pairs. The 5- to 8-year burning frequency to rejuvenate tobosagrass stands for grazing purposes should also increase the number of open forage areas for lark sparrows compared to preburn levels.

"Hot" fires may be detrimental to lark sparrows the year of the burn. The 1974 burn was a hot fire; and although no observations were made on nesting birds at the time, it is assumed that hot fires would reduce the number of potential nest sites by consuming all grass material. A year after the 1974 burn, enough grass production had taken place to provide nest sites approaching the 1975 cool fire levels.

Lark sparrows are shrubland birds (Wiens and Dyer 1975) and require woody plants for perches and they will often nest in the lower branches of shrubs and trees. Complete removal of woody plant species by fire or mechanical means of brush control would have a harmful effect on lark sparrow distribution.

\section{Literature Cited}

Buttery, R. F., and P. W. Shields. 1975. Range management practices and bird habitat values. $I n$ : Symposium on the management of forest and range habitats for non-game birds. U.S. Dep. Agr., Forest Serv. Gen. Tech. Rep. WO-1. $342 \mathrm{p}$.

Conover, W. J. 1971. Practical nonparametric statistics. John Wiley and Sons, Inc., New York. 462 p.

Hayne, D. W. 1959. An estimation of the strip census method for estimating animal populations. J. Wildl. Manage. 13:145-157.

Oberholser, H. C. 1974. The bird life of Texas. Univ. of Texas Press, Austin and London. 915 p.

Wiens, J. A. 1974. Climatic instability and the "ecological saturation" of bird communities in North American grasslands. Condor 76(4):385-400.

Wiens, J. A., and M. L. Dyer. 1975. Rangeland avifaunas: Their composition, energetics, and role in the ecosystem. In: Symposium on the management of forest and range habitats for non-game birds. U.S. Dep. Agr., Forest Serv. Gen. Tech. Rep. WO-1. 342 p.

Wright, H. A. 1969. Effect of spring burning on tobosagrass. J. Range Manage. 22:425-427

Wright, H. A. 1972. Fire as a tool to manage tobosa grasslands. Proc. Annu. Tall Timbers Fire Ecol. Conf. 12:153-167.

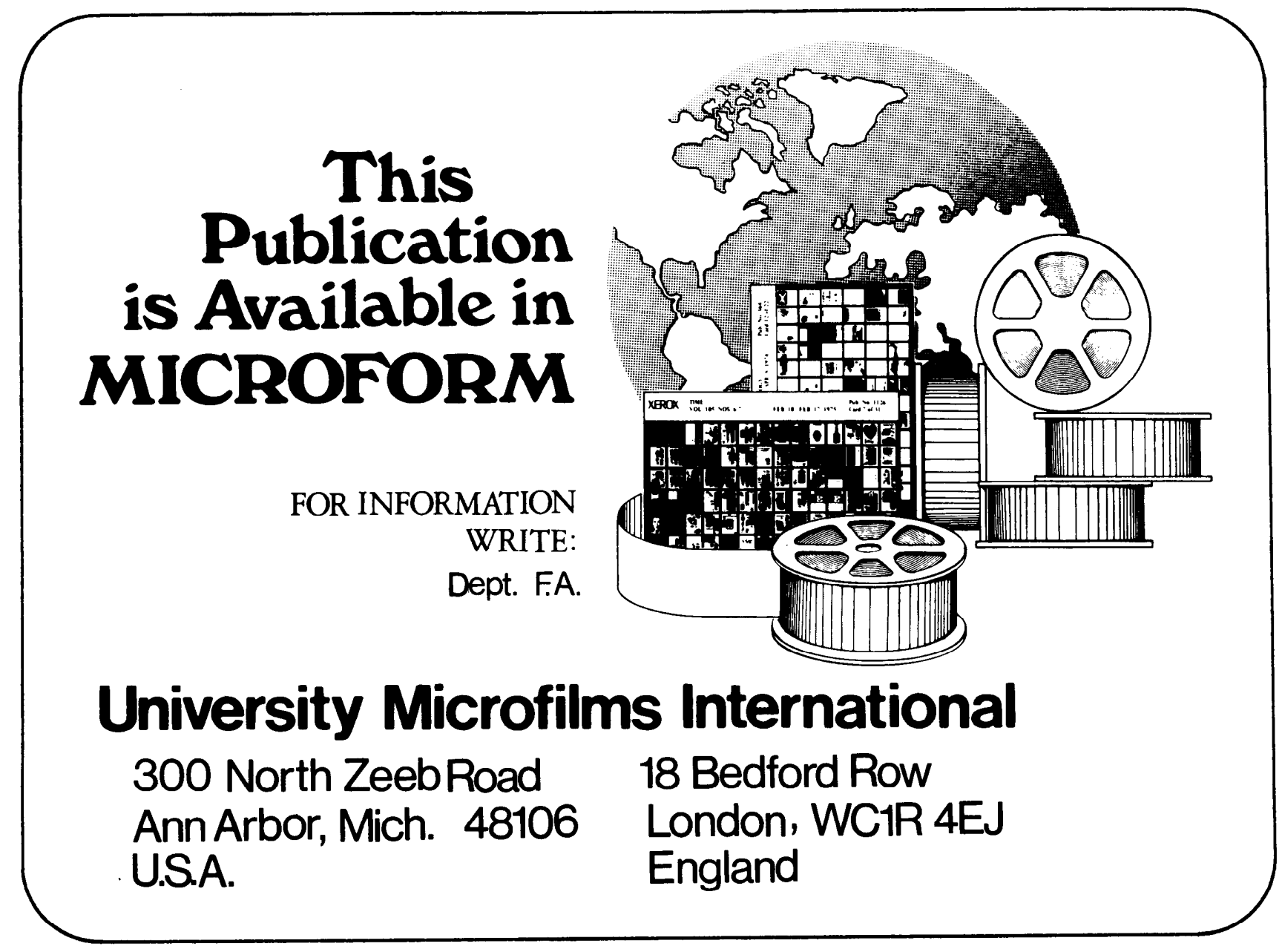

